\title{
SUBSTANTIATION OF PROJECTS IN THE SPACE DEBRIS MARKET IN THE AGE OF NEW SPACE
}

\author{
Tetiana Hilorme ${ }^{1}$ \\ Mykola Dron"2
}

DOI: https://doi.org/10.30525/978-9934-26-077-3-23

Abstract. The article highlights research, dedicated to the study of the peculiarities of justification of the projects in the emerging space debris market in the age of New Space. It has been proved that humaninduced debris in orbital space has reached catastrophic proportions, which requires making immediate changes for sustainable development of space activity. The research objective resides in the development of theoretical and methodological foundations, scientific and methodological approaches, and a practical toolkit for justifying projects in the emerging space debris market. The methodological platform of the research included the Stakeholder concept as an eco-system of interrelated groups. One built the BCG matrix of growth of the "Access to outer space" sector of the global market of space products and services. Also, there were distinguished four groups of space services for this segment using two factors - "the share of the types of space services" and "the relative share of the service market." During the research, the authors developed a matrix for analysis of the project stakeholders in the emerging space debris market. It has been identified that there are three groups of stakeholders by the factors' levels "Influence - Interest": partners - alpha-stakeholders ( $\alpha$-stakeholders), consultants and support - beta-stakeholders ( $\beta$-stakeholders). A situational model for the choice of a negotiating strategy for the development of projects in the space debris management market has been developed based on the methodological approach of "decision tree" to determine a rational negotiating strategy for reduction of destructive behaviour and avoidance of

\footnotetext{
${ }^{1}$ Doctor of Economic Sciences, Associate Professor,

Leading Research Scientific Research Institute of Power,

Oles Honchar Dnipro National University, Ukraine

${ }^{2}$ Doctor of Technical Sciences, Professor,

Professor of the Department of Design and Construction,

Oles Honchar Dnipro National University, Ukraine
} 
organizational conflicts among residential stakeholders. It was proposed to determine the general efficiency of the projects in the emerging space debris market based on the methodology by M. Farrell: as production of technical effectiveness and allocative (distributional) efficiency. All components of general efficiency were analyzed by the authors who also provided analytical calculation formulae: technical, economic, social, and ecological. A method of determining expenditures for a project on emerging space debris on the assumption of an alternative cost of projects and determining the stage of the project's life cycle has been proposed. Making decisions on the project development requires structural analysis of expenditures of operating activity by the life cycle stages. To do that, the operating activity costs should be structures in the following way: preproduction costs; production costs; off-production costs; postproduction costs. The following main parameters used for making managerial decisions during project development were considered: profitability, the cost of deferred decisions, and deviation from costs. It was discovered that project development is carried out in the risk and uncertainty conditions. The authors formed a system for assessing risks, related to financing of the projects on recycling of space debris, which grounds on risks classification (technical, financial, procedural), which enabled the possibility to develop risk management strategies. The risk groups were analyzed following the requirements of stakeholders.

\section{Introduction}

In the age of New Space, humanity faces a global problem related to the limitations of space orbital area. The sustainable development of space activities will be possible only when space users implement technologies and practices suitable to avoid the accumulation of objects in the orbit [6]. Man-induced debris in orbital space has reached catastrophic proportions. As of 2020 , about $85 \%$ of space objects belong to the class of non-controlled satellites [10].

As a result, one observes the appearance of the Clean Space concept in the global economic space [1]. In response to the above-given requirements, the Clean Space initiative will be built upon three building blocks: EcoDesign designing to address environmental impacts; CleanSat - designing to reduce the production of space debris; eDeorbit - removing a large piece of space debris from orbit, such as the Envisat satellite [1]. 
Within the framework of this concept, more innovative projects are being developed to build a system of a combined method for the removal of space objects from the circumplanetary orbits $[2 ; 5 ; 14 ; 15]$. This brings up to date the scientific search in the area of project management of space projects: determination of efficiency, risks, barriers, etc.

The research objective resides in the development of theoretical and methodological foundations, scientific and methodological approaches, and a practical toolkit for justifying projects in the emerging space debris market.

\section{Survey methodology}

The theoretical and methodological foundation of the research included modern theories, concepts, and hypotheses. The study included the use of such general scientific and specific methods that ensure the reliability of the obtained results and findings: dialectic, gnoseological, and logical, in particular, the terminology analysis - to study the conceptual and categorical apparatus and clarify the basis for making managerial decisions; induction, deduction, scientific abstraction, and generalization - to justify economic categories and definitions; monographic and comparative - to systematize scientific approaches to concretizing the theoretical foundations of expanding the methodological basis of management; structural analysis to determine expenditures by lifecycle stages; techniques of the abstract and logical method - to develop theoretical and methodological generalizations and formulate conclusions upon the research results.

One also used the stakeholder concept tools (Stakeholder concept) as an ecosystem of interconnected groups, the interests of which should be considered and satisfied, the project management system should ensure the creation of value for its stakeholders as well.

\section{Findings}

In the New Space epoch, the global market of space products and services is expanding. This is primarily due to an increase in the range of space services at an expense of entry into the market of commercial organizations. One distinguishes five sectors of commercial space activity in the XXI [2]: access to cosmic space; remote sensing and scanning; access to satellite data and analytics; space stations; and spacecraft beyond Earth's orbit. 
According to the data of Bryce Space and Technology, external investments in launching new space firms increased by $\$ 500$ million per year over the period from 2001 to 2008 , and by $\$ 2.5$ billion per year for the period from 2015 to 2016 [9].

The most developing sector of commercial space activity is access to outer space, which performs provision of the following basic services: orbital launches of satellites and ISS cargo; transportation to the Moon; crewed LEO, lunar transport, and tourism; crewed LEO transportation; suborbital launches, human spaceflight; cargo and crewed LEO transportation; space tourism \& rapid commercial flight; reusable launch vehicles, colonization; suborbital launches of small payloads; launch vehicles and engines.

Figure 1 shows the BCG matrix of growth of the "Access to outer space" sector of the global space products and services market.

To carry out analysis of growth of the market segment, one forms four groups: 1st group $-90 \%-120 \%$; 2nd group $-50 \%-89 \%$; 3rd group $10 \%-49 \%$; 4 th group $-1 \%-9 \%$. The first group is characterized by an increase in two factors - the "share of the type of space services" and the "relative share of the service market": orbital launches of satellites and ISS cargo.

The second group is characterized by an increase in the "share of the type of space services" factor and a decrease in the "relative share of the service market" factor: transportation of the crew to low Earth orbit (LEO); Crewed LEO transportation; Space tourism; rapid commercial flight. The third group is characterized by a decrease in the "share of the type of space services" factor and an increase in the "relative share of the service market" factor: Transportation to the Moon; Suborbital launches, human spaceflight; Cargo and crewed LEO transportation; Reusable launch vehicles, colonization; Suborbital launches of small payloads. The fourth group is characterized by an increase in the "share of the type of space services" factor and the "relative share of the service market" factor: Crewed LEO, lunar transport, and tourism.

The orbital launching of satellites and cargo to the ISS is primarily due to an increase in the adjacent market - the telecommunications market. According to Deloite forecasts, in 2021, the global market of intelligent peripheral devices will grow to 12 billion US dollars with an average annual growth rate (CAGR) of about $35 \%$ [4]. 


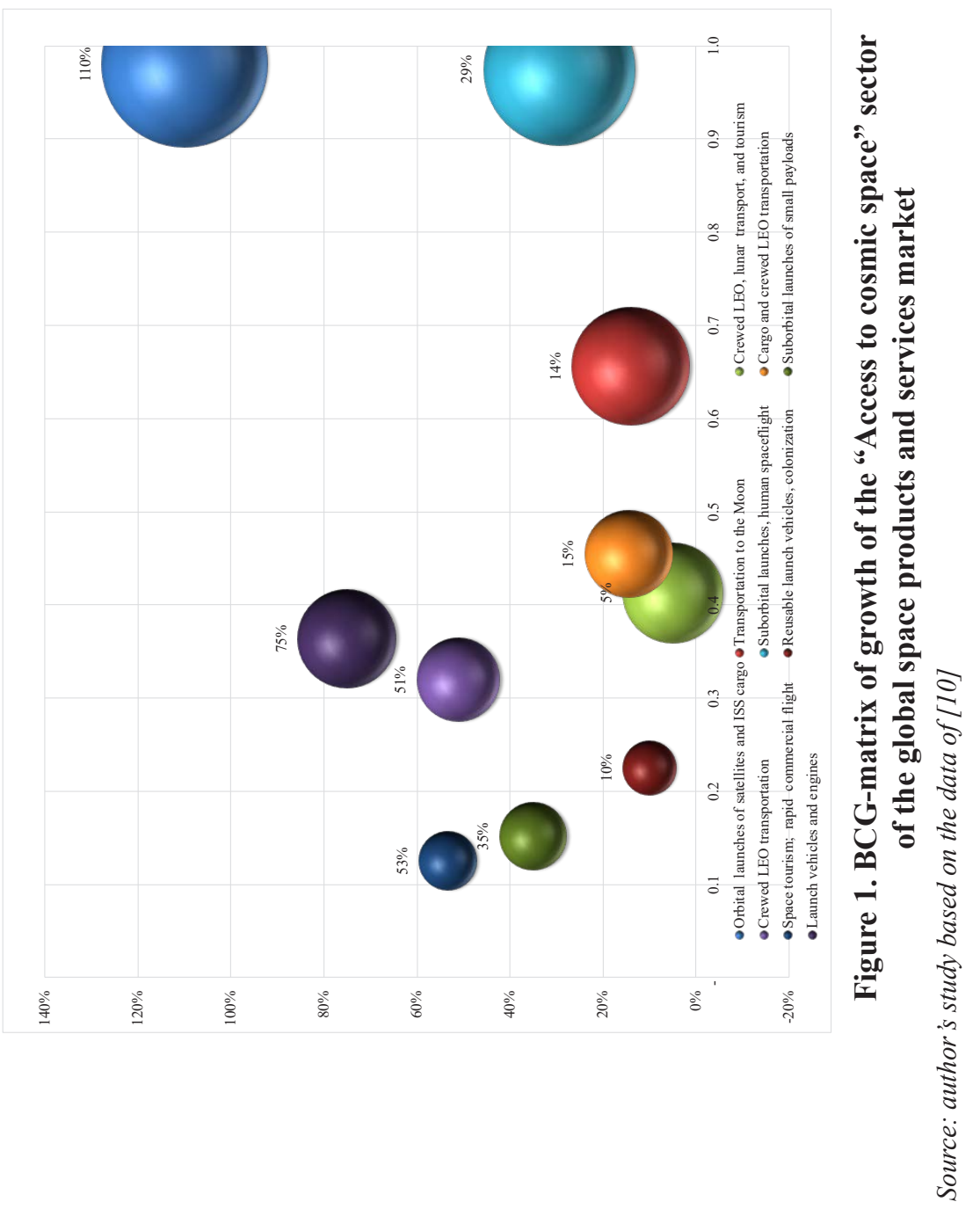


When it comes to the service "space tourism," it should be noted that tourism related to low Earth orbit (LEO), according to Figure 1, belongs to Group 2, while lunar tourism is in Group 4. Thus, according to a report by the Boston Consulting Group, by 2025, an increase in the market share of space tourism services (the share of luxury travel) will lead to an increase in the profits of this service by $\$ 1.8$ trillion [8].

In the XXI century of the emerging space debris market, there is the influence of the corresponding stakeholder groups (interested parties). To the primary circle of external stakeholders on the international market, one can include: space agencies, meteorological, defence agencies, commercial satellite operators, insurance companies (responsible for covering losses from space debris), etc.

The identification of the project's interested parties and understanding their relative influence on the project is an important task. Failing to do this may significantly increase the project's implementation time, and, as a result - increase expenditures for its implementation.

The primary objectives of the interested stakeholder group's analysis:

- determination of principles of management system construction with consideration of group interests;

- determination of border values of the confidence coefficients for determination of the trust level to management system construction with consideration of group interests;

- determination of efficiency assessment criteria based on social behaviour models and choice of characteristics of agents interaction with consideration of the principle of the maximum expected usefulness;

- development of an efficiency assessment methodology considering the system of indicators from the point of view of its and related group interests by areas of economic feasibility;

- justification of theoretical foundations on possibilities expansion for the formation of the integrated communications with the provision of expediency, relevance, and objectiveness;

-improvement of methods for diagnosing conflicts of the group interests;

- development of a system of measures on counteraction to decrease in the destructive interaction of economic groups using the frames.

Analysis of the interested parties should be carried out at each stage of the development and implementation of the project implementation plan. 
In the preparatory phase, the purpose of the analysis is to pre-identify the key interests of stakeholders. The main objective of the interested parties management resides in the identification of their expectations, meeting their needs, and removal of obstacles that lead to a conflict of interests.

Engagement of stakeholders is a specific type of activity dealing with creation of opportunities for holding a dialogue between a company and one or several of its stakeholders for provision of the information basis for the company's decisions. The close circle of stakeholders (primary stakeholders) includes: personnel, owners, clients, and business partners.

The far circle (secondary stakeholders) manifests itself as an indirect influence: a state, competitors, investors, local communities (media, public organizations, etc.). Both circles represent an interdependent system, a web, which supports implementation or, vice versa, does not enable the possibility to take the necessary measures to implement innovative projects. The creation of the stakeholder definition platform is carried out in systemic engineering. An understanding of who is a stakeholder with regard to decisions that are made should be established beforehand.

One carried out an analysis of the stakeholders of the project on the construction of a system of a combined method for the withdrawal of space objects from the near-Earth orbits. One constructed a matrix upon the factors "Influence-Interest" (Figure 2): influence (x-axis) is the degree of stakeholders' influence on the project; interest (y-axis) resides for the project objectives that are common and desirable for interested parties.

According to the results of the analysis, three groups of stakeholders were identified by the levels of factors "Influence-Interest": group 1 ("highhigh") - Governments/Space Agencies, Traditional Space Industry; group 2 ("low-high") - Aviation industry, Insurance and legal companies; group 3 ("high-low") - Manufacturers/Operators, Telecommunications, Service providers. Stakeholders of the first group (partners) actively influence and are to the maximum fixed in the development of the emerging space debris market. The partners are the main stakeholders of the project who should be involved in making decisions on the project as much as possible. It is necessary to increase the interest of the group in the project and fully satisfy its needs. It is recommended to use the principle of partnership in communication during negotiations on a project with this group. 


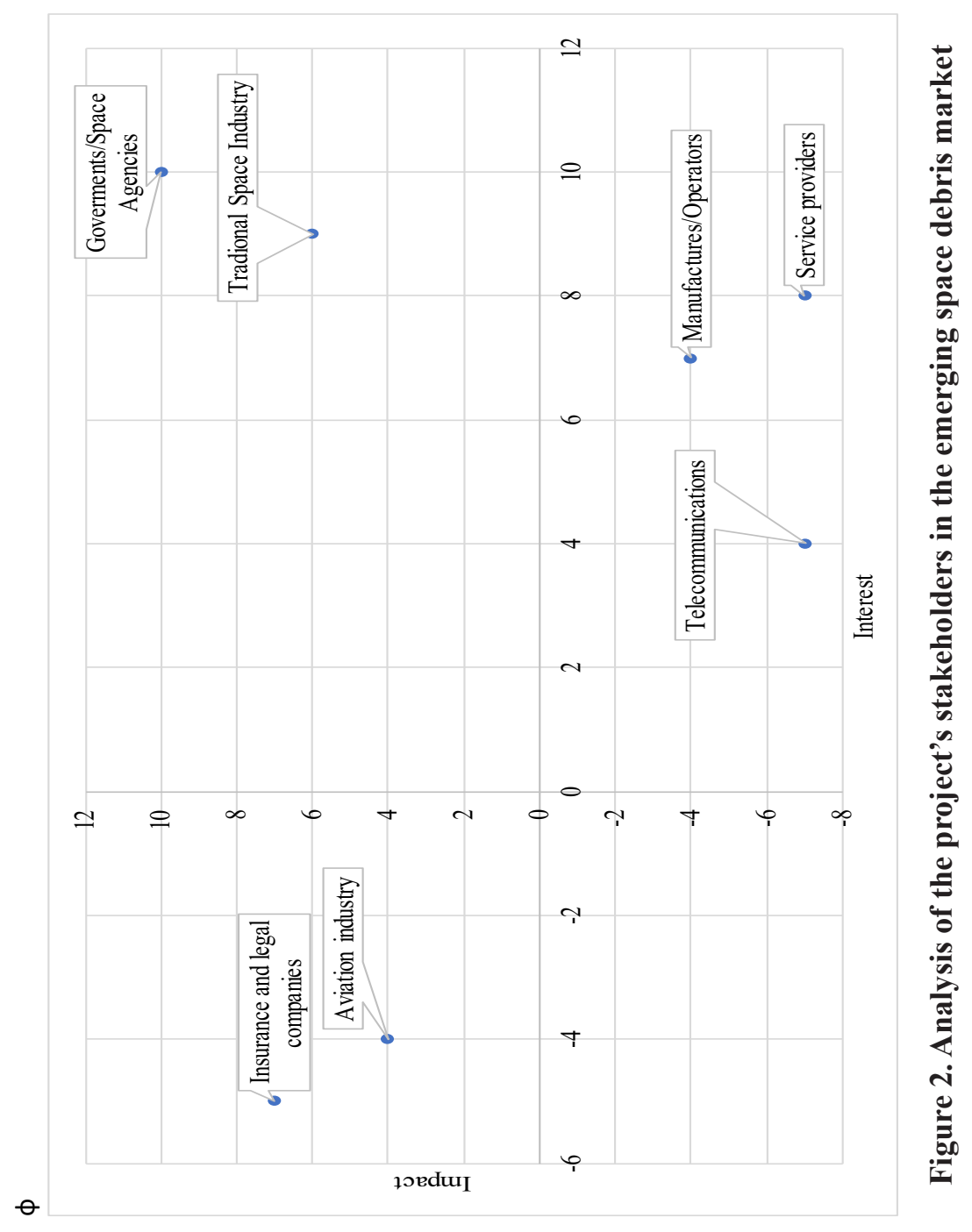


The stakeholders of the second group (consultants) are the stakeholders of secondary importance. It is recommended to engage it as consultants and for agreement of only important strategic decisions on the project.

The stakeholders of the third group (support) are the stakeholders of secondary importance. This group should be familiarized with all key decisions on the project, despite the fact that it does not take direct participation in making decisions on the project. Hereby, it is recommended to engage this group in the discussion of the possible problems and gain additional support from it when making important decisions.

The first group of stakeholders is called the alpha-stakeholders ( $\alpha$-stakeholders) of the project, the second and the third group - betastakeholders ( $\beta$-stakeholders).

The organizational support of the project includes management of the organizations' capacities of supplying and buying products and services through support, initialization, and project management. This support ensures resources and infrastructure needed to facilitate projects and guarantees implementation of the organizational objectives and existing agreements.

Depending on the project's life cycle stage, one observes changes in the structure of the beta-stakeholders, for example: at the stage of "Logistics and Maintenance" - supporting services, instructors, and participants of the supply chains.

It is possible to distinguish four sectors of the implementation of the innovative projects, within which the stakeholders operate: technical, portfolio management, quality management of marketing promotion, and risk management.

In particular, when managing risks, one observes formalization of the process: it contains a description of risk categories, stakeholders' perspectives and description (possible using the reference) of technical and managerial tasks, assumptions, and restrictions. It is important to build and maintain a risks profile, each record of which should contain the importance of the risk. Importance is determined by the risk criteria provided by the stakeholders.

The essence of the corresponding risk profile should be reported periodically to the stakeholders depending on their needs, since the risk profile may change if a particular risk state is updated. 
One considers it important to note that the personnel of the enterprise is a key factor in levelling procedural risks (direct impact), and indirect impact - technical (quality of work of specialists in the area of engineering and employees) and financial (competence of financial analysts of the enterprise and senior management). It is the main close circle of stakeholders of each business entity. That is why it is necessary to build a human resources strategy for staff development.

It is determined that the main causes of conflict include the difference between the interests of project managers and team members; ambiguous definition of the communication type in the management organizational structure; the imbalance of responsibilities, powers, and duties in the project; violation of rules of team formation and functioning and authority delegation in the project. Conflict management includes the impact of resolving the cause of a dispute, modification of participants' behaviour, and maintenance of a controlled level of the dispute.

An analysis of the style and strategy of the negotiations and the development of different possible development scenarios established practical recommendations for the project manager on holding negotiations between the interested parties. The recommendation resides in the use of different tools: oppression, regulation, conflict resolution, the use of the capabilities of the panel of arbitrators (consultations, mediation, and arbitration procedures).

It is time to have a closer look at the strategies of holding negotiation of the main project stakeholders (partners) based on the developed matrix "partnership-activity" to increase negotiations' efficiency: avoidance, passive friendship, complete and partial concessions, compromises, passive conflicts, tough ethical competition, and constructive cooperation.

Following the proposed negotiating strategy based on the methodological approach of "decision tree," one developed, a situational model for the choice of rational strategies of holding negotiations, including the solution of conflicts between the interested parties, which take place based on the "decision tree" approach (Figure 3). This will enable the possibility to determine a rational strategy for holding negotiations for the reduction of destructive behaviour and avoidance of organizational conflicts from the project's interested parties. 


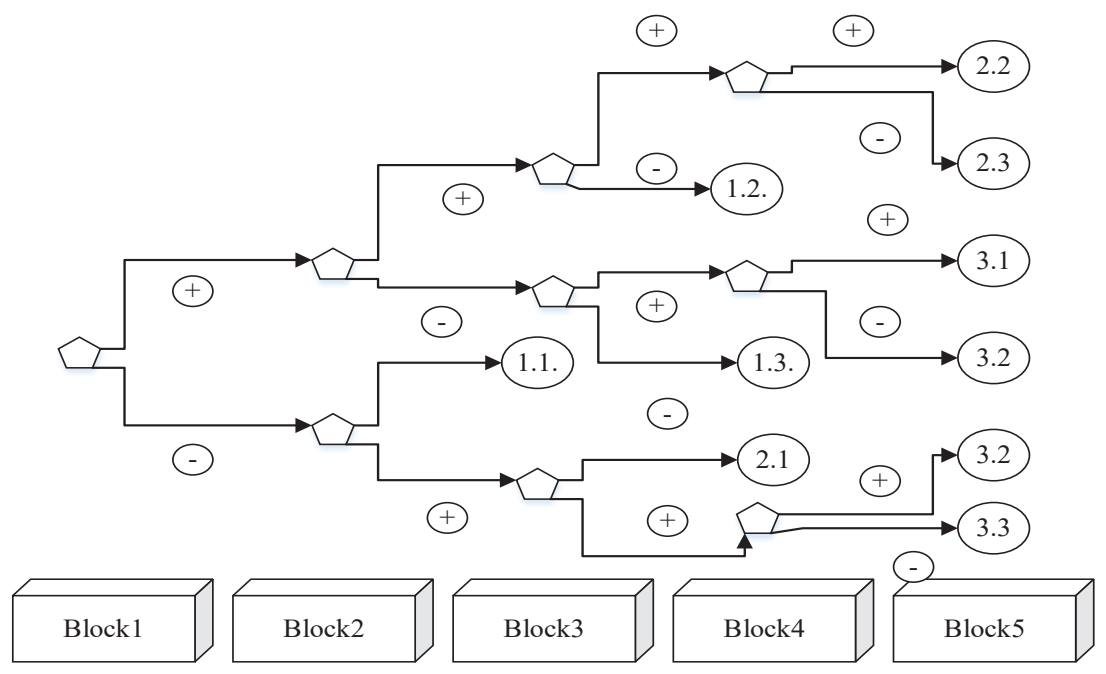

Figure 3. The situational model of choice of a strategy for holding negotiations during the development of the projects on the emerging space debris market

Notes: Block 1 - Is the topic of negotiations significant for the stakeholders? Block 2 - Is the topic of negotiations significant? Block 3 - Are they important for the further relationship with stakeholders? Block $4-$ is maintaining relationship important for stakeholders? Block 5 - Is there a balance of powers between stakeholders?

A "decision tree" is built based on the obtained data. Its structure includes the nodes which stand for key events (decision points) and branches (implementation of these decisions) that connect the nodes. As a result of "decision tree" construction, one calculates the probability of each negotiation scenario in the project.

When developing projects, the business entity faces the need to choose from among the available limited alternative resources: money, labour, material, etc. Making decisions on project development is carried out by the company's management, which increases the subjectivity of this decision for many reasons, including mentality, professional experience, judgments, etc. To reduce the subjectivity of calculation of profit growth thanks to the project development, it is necessary to refer to methods for assessing projects from the area of social diagnostics. 
When assessing the effects while choosing from several alternative projects, it is necessary to consider not only the economic effect (as achievement of the highest results by the enterprise at the slightest cost of living and speech labour or reduction of the total cost per unit of production) but also social and environmental effects. Hereby, it is necessary to assess these effects from the point of origin: international and external.

There are several scientific schools on the determination of efficiency in the scientific area under the study [11-13]. Thus, for large-scale projects of state importance, including space and rocket systems, space systems, etc., depending on the field of application of the obtained results, there may be the following types of useful effects: direct economic or commercial effect; indirect economic effect; technological effect; effect in the national security and defence; social effect; environmental effect; foreign policy effect [17].

Yoshida H., \& Araki M. consider the overall effectiveness of projects in the emerging space debris market as a combination of three components: social, political, and economic [16]. Hereby, it is noted that it is the social component that has a priority influence on overall efficiency. Maclay T., \& McKnight D. Put an emphasis that the main effect of the projects and programs in the emerging space debris market resides in the environmental effect [7]. This should influence the issuance of licenses to commercial companies on recovery of space debris - protection of the national security of the country from environmental risks associated with man-induced disasters in the orbit. Ellery A., Kreisel J., \& Sommer B. determine the effectiveness of programs on the emerging space debris market from the point of view of forming an effective infrastructure in the orbit [3]. They note that the further development of robotics will increase the overall effect, especially a technical one.

Thus, it is necessary to determine the effectiveness estimates of the proposed innovative technical solutions on the principles of the theory of the relationship between productivity and efficiency (M. Farrell's technique). Production productivity, as well as efficiency, is determined by the ratio of the final product (English "output") to the incoming factor (English "input").

The analytical formula of general effectiveness (GE) has the following form:

$$
G E=T E \times A E ; 0 \leq G E \leq 1 .
$$


According to M. Farrell's methodology, efficiency is the ratio of the actual productivity of the enterprise to the maximum possible productivity. M. Farrell considers the general effectiveness (GE) as production of technical efficiency (TE) and allocative (distributive) efficiency (AE). Allocative efficiency appears when the business entity faces the choice of selecting resources for production at these prices with minimal costs and determines how close are the solutions with the minimal costs and technically efficient solution.

Technical efficiency of the diversion system is increased by reducing the diversion time, the mass of the system, the energy consumption for its inclusion and deployment, under reduction of the complexity of manufacturing and assembly, the cost of the system, while the reliability indicator should increase [20].

Technical effectiveness can be determined through the system's project efficiency criterion of the combined method of the space objects removal from the near-Earth orbits:

$$
\overline{T E}=T E(\tilde{T}, \tilde{M}, \tilde{W}, S, R) \rightarrow \max .
$$

where $\overline{T E}$ - project efficiency criterion; $\tilde{T}$ - relative time of removal; $\tilde{M}$ - mass ratio of the object; $\tilde{W}$ - the amount of energy consumption; $S-$ producibility of the system; $R$ - reliability of the system.

The producibility of the system is a conditional indicator, showing the structural complexity of the manufacture of elements and the system for space objects removal from the near-Earth orbits. As a rule, it is determined by the method of expert assessments.

The reliability of the system is a generalized indicator, the possibility to remove space objects from the near-Earth orbits, the probability of failurefree operation, and performance of the objective function, is determined by the method of expert assessments.

Thus, the allocative (distributive) efficiency (AE) of projects in the emerging space debris market can consist of three effects: economic, social, and ecological.

Thus, the internal environmental effect is a decrease in the sum of environmental payments, a reduction in environmental losses of the enterprises, social - an increase in the level of motivation of staff, a decrease in payments for industrial injuries, etc. 
It is beyond argument that restrictions in the financial resources allocated to the development of projects in the emerging space debris market, under the task of maximizing the economic effect, it is advisable to select projects based on a mathematical model:

$$
\left\{\begin{array}{l}
L C C_{i}<B_{t}, \\
E_{i}^{E c}+E_{i}^{S}+C o D_{i}>L C C_{i}, \\
a t: L C C_{i} \rightarrow \min , \\
E_{i}^{E c}, E_{i}^{S}, C o D_{i} \rightarrow \max ,
\end{array}\right.
$$

where $L C C_{i}$ - expenses of "life cycle" of the $i$-th пproject on energysaving, monetary units; $B_{t}$ - budget on implementation of the projects in the $t$-th year, monetary units; $E_{i}^{E c}$ - ecological effect, related to the implementation of the $i$-th project, monetary units; $E_{i}^{S}$ - social effect, related to the implementation of the $i$-th project, monetary units; $C o D_{i}-$ the cost of the deferred decisions, related to the implementation of the $i$-th project, monetary units.

It is necessary to disclose the peculiar features of the time calculation indicator for the return on investment of the projects in the emerging space debris market - the "life cycle" cost (of the project) (LCC).

Inclusion of all expenses and savings that are spent during the "life cycle" is an opportunity to assess projects' profitability. This approach - the "life cycle" cost (LCC) of the project - can be adopted by the management of the enterprise as the antithesis of the necessary project procedures under the absence of functional responsibilities with the rapid innovative development of technology for minimizing the total costs.

LCC - is a time-consuming calculation, but all efforts are justified by a survival strategy. The "life cycle" costs (LCC) help to estimate the net profit during project development with consideration of all basic costs and savings, discounted to the relevant value of money. Thus, the additional questions (calculation of the discounted value, discount factors and rates, LCC) require a detailed analysis. One developed the following formula of the "life cycle" cost (of the project) (LCC), considering the peculiarities of the project:

$$
\mathrm{LCC}=\mathrm{In}-\mathrm{S}+\mathrm{M}+\mathrm{R}
$$

where LCC - "life cycle" cost (of the project); In - initial investments in the project; $\mathrm{S}$ - salvage value of the equipment as active for the end date of 
the target depreciation period of this asset; $\mathrm{M}$ - money expenses during the project (program); $\mathrm{R}$ - running costs needed for equipment removal.

The cost of deferred decisions (CoD) enables the possibility to determine alternative scenarios "with a project - without a project." Hereby, one provided the corrected formula for calculations $\mathrm{CoD}$, considering the peculiarities of the project:

$$
C o D=-(L e+L b)+I n,
$$

where $C o D$ - the cost of deferred decisions; $L e$-economic consequences of the change in technology; $L b$ - saving costs during the project (program); In - initial investments in the project.

Procedures and methods of investment attractiveness analysis are aimed at identifying alternatives and comparing project implementation options by the performance criterion. Making of a managerial decision on the choice of projects on the emerging space debris market grounds on the assumption of the alternative cost of the projects - it is proposed to determine complex economic efficiency and their comparison:

$$
E_{e n}=\frac{\sum_{n=1}^{N}\left(W_{0}-W_{1}\right) \times c_{n}+E^{E s}+E^{s}+C o D+\Delta P_{r e p}^{\text {perm }}}{L C C+P_{\text {cred }}+D_{e q}},
$$

where $E_{e n}$ - economic effect from the project's introduction, monetary units; $W_{0}, W_{1}$ - the volume of the annual consumption of the $n$-th energy resource respectively before and after project implementation; $c_{n}$ - the cost of a unit of the $n$-th energy resource, monetary units; $\Delta P_{\text {rep }}^{\text {perm }}$ - change in the cost of planned ongoing repairs, preventive maintenance and service, monetary units; $P_{\text {cred }}$ - the payment on interest on a loan, monetary units; $D_{e q}$ - costs related to the idle time of production facilities, caused by the project implementation, monetary units.

Making decisions on project development requires holding of a structural analysis of operating expenses by stages of the product life cycle. To do that, operating expenses are structured as follows [19]: pre-production (development of product formation, manufacturing of technological tooling, development of the product for processability, commissioning, purchase of necessary equipment); production costs (direct costs of products, indirect costs of production); non-production costs (administrative and commercial sales costs) post-production costs (disposal of debris and process equipment). Based 
on the results of this analysis, information is generated on the comparability of expenses recognized at the production stage of the life cycle of the assortment part and other operating expenses recognized at the equity, non-production and post-production stages of the life cycle of the assortment part.

The search of reserves for operating costs reduction can be carried out based on the identification of sources of competitive advantage in the value creation chain of the product. To identify sources of competitive advantage, it is necessary to analyze nine interrelated types of activity, which in strategic management form a value creation chain: five main (incoming logistics, production, outgoing logistics, marketing and sales, after-sales service) and four auxiliary (infrastructure of the enterprise, personnel management, technological development, material and technical support). The strategic analysis of operating costs in the value chain is carried out using a comparative analysis of the value chain with direct competitors and in the field of operation.

Hereby, the methodological platform of the formation of planning and forecasting of project expenditures, especially strategic ones, should be based on the concept of cost alternatives.

Hereby, one observes the formation of the phenomenon of "decoupling of influence" - it is relevant when using resources that can pose a threat to human health and the state of the ecosystem or when technological solutions have a significant potential for reduction of threats to humans and the environment. It does not always appear due to reduced use of resources or costs in the production process. The achievement of the decoupling effect often requires a change of the technological processes, which requires considerable investments [18]. First of all, it is urgent in projects and programs in the emerging space debris market.

When developing projects and programs on the emerging space debris market, one observes the appearance of the risks in front of the business entity, which can be conditionally divided into three groups: technical, financial, and procedural.

Qualitative risk assessment is the process of identifying and determination of the risks that require fast response. Such risk assessment determines the degree of importance of the risk and chooses the way for the response. The information accessibility, accompanying them, helps to set priorities for different risk categories. Qualitative risk assessment is the assessment of conditions for risk appearance and determination of their 
impact on the object using standard methods and means. The main task of qualitative assessment is the determination of the possible types of risks, as well as factors, affecting the risks level during the implementation of a certain type of activity. At this stage, it is important to identify all possible circumstances and provide a detailed description of all possible risks.

Table 1 presents the risk groups for the development of projects and programs in the emerging space debris market and strategies for their mitigation.

Technical risks can be managed through analysis of variables (level assessment) and introduction of the corresponding strategies for this risk reduction but under the condition of attraction of internal resources and/or external support.

Almost in all cases (for example, direct buying), there is the highest level of risk for the consumer under the lowest total expenditures.

The general strategy of reducing technical risks includes quality conduction of investment audit, primarily, an investment-grade audit (IGA), which considers the development risks (assessment of the management correspondence level, professional skills and ability of personnel to provide quality operation and maintenance $(\mathrm{O} \& \mathrm{M})$ ).

The financial risk factors are of priority significance in assessing the most cost-effective financing regimes. The risks, related to the regimes of financing, are always large and diverse. To reduce financial risk factors, there is a development of an investment strategy with consideration of investment audit recommendations, the corresponding verification and control.

The procedural risks are connected with the level of personnel qualification at all hierarchical levels: managers (when making managerial decisions), professionals (when choosing theoretical and methodological approaches to the formation of measures and provision of quality practical recommendations on their implementation, high-quality advisory work at all stages of the life cycle), specialists (formation of a quality information base, implementation), and workers (during production/installation).

The maximum risk appears at the stage of forecasting the dynamics of expenses on the development of projects and comparing savings efficiency. For the economic entities, the net financial advantages of the project are an indicator of the presence of hidden costs but do not consider the result of the service the provision and guaranteed savings. 


\section{The risk groups for developing project measures and strategies of their mitigation}

\begin{tabular}{|c|c|c|}
\hline Risk groups & Risk group elements & Mitigation strategies \\
\hline \multirow{8}{*}{$\begin{array}{l}\text { Technical risks } \\
\text { (TR) }\end{array}$} & $\begin{array}{l}\text { TR1: equipment operation } \\
\text { efficiency, durability, } \\
\text { guarantees }\end{array}$ & $\begin{array}{l}\text { specifications quality, the procedure } \\
\text { of choosing a service company, } \\
\text { contract conditions }\end{array}$ \\
\hline & TR2: technical experience & $\begin{array}{l}\text { education of available personnel, hire } \\
\text { of a qualified external consultant }\end{array}$ \\
\hline & $\begin{array}{l}\text { TR3: investments audit } \\
\text { quality, accuracy level }\end{array}$ & $\begin{array}{l}\text { technical skills and assessment of } \\
\text { an auditor, measures on improving } \\
\text { quality of audit conduction }\end{array}$ \\
\hline & TR4: production/installation & $\begin{array}{l}\text { qualification of a salesperson or sub- } \\
\text { supplier }\end{array}$ \\
\hline & $\begin{array}{l}\text { TR5: operation and } \\
\text { maintenance (O\&M) }\end{array}$ & $\begin{array}{l}\text { Improvement of the personnel } \\
\text { qualification, in particular, its } \\
\text { education }\end{array}$ \\
\hline & $\begin{array}{l}\text { TR6: sustainability of } \\
\text { savings }\end{array}$ & $\begin{array}{l}\text { O\&M quality, administrative } \\
\text { management }\end{array}$ \\
\hline & $\begin{array}{l}\text { TR7: verification of savings } \\
\text { (approach, instruments) }\end{array}$ & $\begin{array}{l}\text { need for a change in measurement, } \\
\text { guarantee or the desired accuracy }\end{array}$ \\
\hline & TR8: information support & $\begin{array}{l}\text { application of modern information } \\
\text { technologies }\end{array}$ \\
\hline \multirow{5}{*}{$\begin{array}{l}\text { Financial risks } \\
\text { (FR) }\end{array}$} & $\begin{array}{l}\text { FR1: project savings are not } \\
\text { realized }\end{array}$ & use of external consultancy services \\
\hline & FR2: fixed payments & monthly fluctuations of savings \\
\hline & $\begin{array}{l}\text { FR3: cost of the deferred } \\
\text { decisions }\end{array}$ & $\begin{array}{l}\text { choice of the other way of } \\
\text { implementation }\end{array}$ \\
\hline & FR4: post-contract savings & engineering support, O\&M quality \\
\hline & FR5: no tax exemptions & choice of another investment strategy \\
\hline \multirow{4}{*}{$\begin{array}{l}\text { Procedural } \\
\text { risks (PR) }\end{array}$} & $\begin{array}{l}\text { PR1: poor equipment } \\
\text { selection procedures }\end{array}$ & $\begin{array}{l}\text { quality internal or external } \\
\text { consultancy experience }\end{array}$ \\
\hline & $\begin{array}{l}\text { PR2: enterprise management- } \\
\text { related issues }\end{array}$ & quality preparation of a contract \\
\hline & $\begin{array}{l}\text { PR3: choice of a project in a } \\
\text { critical situation }\end{array}$ & careful preparation of a contract \\
\hline & $\begin{array}{l}\text { PR4: quality of operation and } \\
\text { maintenance; staff education }\end{array}$ & $\begin{array}{l}\text { development of workforce } \\
\text { development strategy }\end{array}$ \\
\hline $\begin{array}{l}\text { General risk } \\
(\mathrm{R})\end{array}$ & \multicolumn{2}{|c|}{$\begin{array}{l}R=T R \times F R \times P R \\
\text { under } P \neq 0 \Rightarrow T R \neq 0, F R \neq 0, P R \neq 0 .\end{array}$} \\
\hline
\end{tabular}




\section{Conclusions}

It was offered to use the "decision tree" method, which enables the possibility to determine the most appropriate tactics before and during the negotiations process, as well as avoid organizational conflicts during projects development depending on the stage of their lifecycle. This made it possible to determine the following strategies for holding negotiations between the project's interested parties: avoidance, passive friendliness, complete or partial concessions, compromise, passive confrontation, tough and ethical competition, and constructive cooperation. A situational model based on an expanded matrix of negotiation strategies has been built to determine ways of choosing the most advantageous strategy for holding negotiations.

One presented a mathematical model of the project selection when setting the task of the economic effect maximization, which considers both economic components (costs of the project's "lifecycle," the projects' budget, the cost of deferred decisions), and social and environmental effects.

It was found that the development of the projects is carried out under the conditions of risk and uncertainty. One formed a system for assessing the risks, related to projects financing, which grounds on risks classification (technical, financial, and procedural). It has been proven that these risks lead to an increase in the expenditures not only in the money equivalent but also to the appearance of other losses, including: the specific time ranges of loss of the economic benefits, labour force employment ratio, political conditions, etc.

The following directions can be considered the perspectives for further research in the area of efficiency of the projects on the emerging space debris market: development of scientific instrumentarium for analysis, quantitative assessment and forecasting of the development of selforganization and agents adaptation processes; development of a diagram of the group interests influence based on the principle of maximum expected usefulness; development of a model of agents' social behaviour on the principles of sociality and the degree of the elements diversity.

The paper is performed within the framework of the scientific and research projects: S/b topic 4-310-15 "The study of the construction principles of the transport space systems in the condition of the near-Earth space environment pollution prevention," State Registration Number 0115U002402, 
MESU (2015-2016); S/b topic 4-329-17 "Operation patterns of the combined orbit cleaning means considering the dynamics of the near-Earth space," State Registration Number 0117U001211, MESU (2017-2019); $\mathrm{S} / \mathrm{b}$ topic 4-648-20 "Theoretical and experimental justification of autofage systems for space objects diverting from low near-Earth orbits," State Registration Number 0120U102254, MESU (2020-2022).

\section{References:}

1. Clean Space. The European Space Agency. URL: https://www.esa.int/ Safety_Security/Clean_Space

2. Dron, N.M., Dubovik, L.G., \& Kondratyev, A.I. (2010) Characteristics of space debris-gatherers with electric propulsion at two variants of maneuvers of their putting into demanded orbit. Space science and technology, 16(5): 59-61.

3. Ellery, A., Kreisel, J., \& Sommer, B. (2008) The case for robotic on-orbit servicing of spacecraft: Spacecraft reliability is a myth. Acta Astronautica, 63(5-6): 632-648. URL: https://www.sciencedirect.com/science/article/abs/pii/ S0094576508001197

4. Forecast for the development of high technologies, media and telecommunications (TMT). Deloite. URL: https://www2.deloitte.com/global/en.html

5. Golubek, A., Dron, M., Dubovik, L., ... Kulyk, O., \& Khorolskiy, P. (2020) Development of the combined method to de-orbit space objects using an electric rocket propulsion system. Eastern-European Journal of Enterprise Technologies, 4(106): 78-87.

6. Kositsyna, O.C., Dron', M.M., \& Yemets, V.V. (2020) The environmental impact assessment of emission from space launches: the promising propellants components selection. Journal of Chemistry and Technologies, 28(2): 186-193.

7. Maclay, T., \& Mcknight, D. (2020) Space environment management: Framing the objective and setting priorities for controlling orbital debris risk. Journal of Space Safety Engineering, 8(1): 93-97. URL: https://www.sciencedirect.com/ science/article/abs/pii/S2468896720301415

8. Shock of the New Chic: Dealing with New Complexity in the Business of Luxury. Boston Consulting Group Report. URL: https://www.bcg.com/publications/2020/making-a-difference-2019-annual-sustainability-report

9. Start-Up Space: Update on Investment in Commercial Space Ventures. Bryce Space and Technology. URL: https://brycetech.com/reports/report-documents/Bryce_Start_Up_Space_2020.pdf

10. The space report 2020. URL: https://www.thespacereport.org/register/thespace-report-2020-quarter-1-pdf

11. Tkatchova, S. (2018) Space Debris Mitigation. In Emerging Space Markets, 93-105. Springer, Berlin, Heidelberg. URL: https://link.springer.com/chapter/ 10.1007/978-3-662-55669-6 6

12. Tussiwand, G., Antonetti, S., Rossettini, L., \& Di Tolle, F. (2015) Benefits of Adopting a Spacecraft Decommissioning Device to Implement Orbital 
Access Sustainability. In Space Safety is No Accident, 77-87. Springer, Cham. URL: https://link.springer.com/chapter/10.1007/978-3-319-15982-9_9

13. Weinzierl, M. (2018) Space, the final economic frontier. Journal of Economic Perspectives, 32(2): 173-92. URL: https://pubs.aeaweb.org/doi/pdfplus/10.1257/ jep.32.2.173

14. Yemets, V., Dron, M., \& Pashkov, A. (2020) Autophage engines: Method to preset gravity load of solid rockets. Journal of Spacecraft and Rockets, 57(2): 309-318.

15. Yemets, V.V., Dron, M.M., \& Kositsyna, O.S. (2019) Estimation of the Possibilities for Using the Solid Hydrocarbon Fuels in Autophage Launch Vehicle. Journal of Chemistry and Technologies, 27(1): 58-64.

16. Yoshida, H., \& Araki, M. (1994). Social impact of space debris: Study of economic and political aspects. Acta Astronautica, 34: 345-355. URL: https://www.sciencedirect.com/science/article/abs/pii/0094576594902712

17. Alpatov A.P., Marchenko V.T., Xorolskyj P.P., Sazina N.P. (2014) Metodologichni aspekty finansovo-ekonomichnogo obgruntuvannya proektiv kosmichnoyi texniky [Methodological aspects of financial and economic substantiation of space technology projects]. Space Science and Technology, no. 6, pp. 49-59.

18. Hilorme T.V. (2020) Obgruntuvannya upravlinskyx rishen shhodo zaprovadzhennya texnologij energozberezhennya na promyslovyx pidpryyemstvax: teoriya, metodologiya, praktyka [Substantiation of managerial decisions on the introduction of energy saving technologies in industrial enterprises: theory, methodology, practice]. Zaporozhye: CPU, $300 \mathrm{p}$.

19. Hilorme T.V. (2018) Organizaciya obliku ta audytu na pidpryyemstvax v umovax informacijnogo prostoru [Organization of accounting and auditing at enterprises in the conditions of the information space]. Dnipro: FOP Drobyazko S.I., $300 \mathrm{p}$.

20. Krestina A.V., Tkachenko I.S. (2020) Metodika vybora proektnykh parametrov sistemy uvoda malykh kosmicheskikh apparatov s orbity [Methods for choosing the design parameters of a system of small spacecraft with orbit]. Engineering Magazine: Science and Innovation, no. 8, pp. 1-16. 